\title{
Enterprises Accounting for Reward Bonus under the Perspective of Business Law
}

\author{
Shanshan Wang \\ Department of Economics and Management \\ Tianjin Vocational College of Bioengineering, \\ Tianjin, China \\ e-mail: susan_wang2009@126.com
}

\author{
Honglei Liu \\ Department of Economics and Management \\ Tianjin Vocational College of Bioengineering, \\ Tianjin, China \\ e-mail: 1hl124@126.com
}

\begin{abstract}
- in this article, the author defined the elements of accounting reward bonus and determined the accounting method of the enterprise's reward bonus. This truly reflected the financial position and operating results of the enterprise. Though analyzed the legal relationship generated by the enterprise reward bonus, we can use the accounting theory to determine the liability and the accounting method of the reward bonus. The comprehensive use of legal theory and accounting theory can reflect the more real financial position and operating results in the enterprises.
\end{abstract}

Keywords-component; reward bonus; rights; obligations; attribute; accounting treatment

\section{INTRODUCTION}

Enterprise gives the customer reward bonus when they meet the gift condition, after that, the customer can use the reward bonus to exchange the production or the third party's goods and services. Customer reward bonus has a very positive role in expanding the scale of enterprises, improving customer satisfaction and loyalty, encouraging customer to buy goods and services from the enterprises, so it is widely used in many industries.

\section{ANALYSIS OF REWARD BONUS IN BUSINESS LAW}

\section{A. The legal attribute of enterprise release reward bonus policy}

Reward bonus is the enterprise for the customer to maintain the relationship or expand a business selling, which gifts to the enterprise member. The customer can use the reward bonus to exchange the production or the third party's goods and services. This shows that reward bonus has certain value attribute and property rights. The enterprise reward bonus policy often include object, the gift way, and exchange conditions. Its legal attribute for different object has different legal effect, such as:

The first one is the member. Enterprise member is to the person who has already joined in the reward bonus, at this time, the customer and the enterprise come to an agreement about the condition of gift and exchange. This means that there is a gift contract relationship between the enterprise and the enterprise member. The reward bonus policy is just as a supplement or change to the legal attribute of the original contract.

The second is Non-corporate member. The enterprise reward bonus policy often published in commercial advertisement, and said "For details please contact customer service". One of these purposes is to attract the non-corporate member's attention, and hope they can join in the party automatically to enlarge the member scale. Although the policy of enterprise reward bonus including the concrete content, but the rights and obligations did not make specific provisions. As in law, when the content of the treaty is not specific, meaning is not clear, and the body is not specified, we define the invitations for offer.

\section{B. The legal attribute of customer to participate or consume in reward bonus}

Customer joins in the award bonus activity should become to the enterprise member on the premise. The customer issued to the enterprise want to accept the gift of bonus, which is defined as the offer and enterprise applies for membership registration should be defined as the commitment. Since the membership registration completed, customer and the enterprise has reached a conditional gift contract relationship.

Whether it is the first time to customer to buy something, or shopping reaches a certain amount, its purpose is to achieve the policy condition of reward bonus. In the conditional gift bonus contract, the establishment or not of the gift contract related to the effectiveness. When the condition is not yet achieved, although the gift of rights and obligations already clear, the effect is uncertain. When the condition is fulfilled, the legal effect of the gift contract is produced, and it cannot be revoked. Therefore, customer gets reward bonus by consumer has made the contract effectiveness.

\section{SIGNIFICANCE FOR REWARD BONUS BUSINESS LEGAL ANALYSIS}

\section{A. Clear the enterprise reward bonus for the relevant rights and obligations}

Though the legal analysis of reward bonus for the enterprise, not only defines the legal relationship between the customer and the company, but also makes clear the subjects who own the right and undertake the obligation in the legal relationship.

Business gift reward bonus to customer often comes with certain conditions, such as first registration or consumption presented for a certain level. China's "Contract Law" forty-fifth stipulation: the parties to the contract may stipulate the conditions attached. The contract with entry into force conditions, such condition 
is satisfied. A contract subject to a condition subsequent, failure condition is satisfied. Obviously, there is the reward bonus conditional gift contract between the enterprise and customer.

As long as the customer's purchase behavior to meet the condition stipulated in the enterprise gift policy, it formed a reward bonus gift contract between businesses and customer in force, then the enterprise shall gift the customer reward bonus in accordance with the policy agreement. To obtain the bonus customer enjoys certain economic rights in the enterprise, at the same time, enterprises are also bear the corresponding economic duty, and the duty is determined. That means when customer get bonus and reach the exchange standard, you can always request enterprises to fulfill their redemption obligations.

\section{B. Provides theoretical support for enterprise accounting reward bouns}

Through to the enterprise reward bonus service legal analysis, we make clear the responsibility of the enterprise, namely the enterprise has the economic obligations to the customer in the reward bonus gift behavior. "Accounting Standards for Enterprises - Basic Standard" the fourth chapter twenty-third provisions: enterprise liability is a past transaction or event, expected to result in a present obligation outflow of economic benefits of enterprise. Present obligation refers to the obligations of company under the current condition is assumed. Obligation transactions or events occur in the future formation does not belong to a present obligation, so it should not be recognized as a liability. "Accounting Standards for Business Enterprise - Basic Standard" the fourth chapter twenty-fourth liability recognition condition also made specific provision, associated with the obligations of economic interests is likely to flow out of the enterprise, the future outflow of economic benefits amount can be measured reliably. Apparently, enterprise based on reward bonus services to customer have a present obligation, and this can be measured reliably, therefore, in accountings, business gift reward bonus service shall be formed by the obligation was defined as the enterprise debt.

\section{THE PROBLEM OF DEFERRED INCOME FROM THE PERSPECTIVE OF LAW}

In china, the current accounting standards for business enterprise did not make clear about the reward bonus from the enterprise gift, but according to the provisions of Accounting letter to [2008] 60 files, the current accounting method used is deferred income approach, through to the enterprise reward bonus service legal analysis, the author thinks that the current accounting method has the following problems:

\section{A. This accounting method cannot reflect the enterprise external obligations}

In deferred income method, the income should be allocated between the fair value of reward bonus and the payment or trade receivables in the sale of goods or provision of services, the revenue payment or trade receivables net of the fair value recognized as income, the fair value of the reward bonus should first as deferred revenue until the customer redeem reward points or failure, profit or loss carried forward. This use of deferred income approach considers the impact of enterprise bonus gift behavior profit or loss, but it ignores the existing obligations of enterprise behavior to customers based on credit gift shouldered. Using deferred revenue method can only provide business gift sales of goods or services reward bonus for accounting, while customers in other ways cannot get bonus accounting. "Accounting Standards for Enterprises Basic Standard" the second chapter twelfth provisions: Enterprise transactions or events should actually occurred as a basis for accounting recognition, measurement and reporting, compliance with accounting information accurately reflects elements to ensure reliable accounting information and content integrity. However, the use of deferred income method accounting for enterprise reward bonus, its accounting scope is not comprehensive, underestimate the enterprise debt, cannot reflect the corporate responsibility, and also cannot guarantee the reliability of accounting information and content integrity.

\section{B. Lack of specification for reward bonus of accounting}

Reward bonus as an enterprise gift contract with the customer is an important subject in the accounting, so it should be given full reflected. However, whether in theory or in the practice of accounting, the reward bonus is not standardized, mainly in the following two aspects: On the one hand, it lack of basic accounting information about reward bonus. When the enterprises gift the reward to their customer, there is no record about the reward bonus in the original document or it just statistics the numbers. This shows that the companies do not have the measurement value of reward bonus, so there is no relevant record in books. On the other hand, using the method of deferred income to measure the reward bonus fair value, in the practice the value is not fully in accordance with the fixed pricing model to determine the estimate, mostly obtained by estimating, and this tends to underestimate the enterprise obligations, and also underestimated enterprise liabilities.

\section{BUSINESS ACCOUNTING ABOUT REWARD BONUS IN LEGAL PERSPECTIVE}

Enterprise accounting shall faithfully reflect the rights and obligations. The accounting should be carried out in strict accordance with the "Accounting Standards for Enterprises - Basic Standard" accounting information quality requirements.

\section{A. The enterprise should enhance the accounting about reward bonus}

Original documents are raw data and important basis of accounting, the subject of reward bonus which is the corporate and customer gift contract, should be reflected in the original documents, not only to reflect the quantity but also the value. Meanwhile, in the corporate books should also be accounted for the number and value about reward bonus, enterprise bonus policy is directly determine the value which should also be included in the raw accounting data. 


\section{B. The enterprise should confirmed the obligations generated by reward bonus}

Enterprise gifts reward bonus to the customer, should be in accordance with the fair value, so it debit "selling expenses" account, credited to "estimated liabilities" account. When the customer exchange bonus, according to the actual receipt or should receive payments debit "cash", "bank deposit" or "accounts receivable" account, according to the reward bonus fair value debit "estimated liabilities" account, credited to "main business income" and "tax payable -- VAT payable" account. When customer exchange bonus to the third party with the fair value of debit "estimated liabilities" account, credited to "cash", "bank deposit" or "accounts payable" account. If the customer overdue exchange bonus, the enterprise shall expire in accordance with the fair value of the bonus debit "accrued liabilities" account, credited to "operating income" account.

\section{The enterprise should accurately calculate the burden obligations}

Because different redeem policy adopted by enterprises in different periods, the value of reward bonus are also different, so them to be measured at fair value. When the enterprise gift bonus, they should first confirm quantity, then according to the current exchange policy to calculate its fair value, if the policy adjusted, the enterprise should follow the principle of prudence to fair value on the reward bonus re-measurement. When the increase in fair value of reward bonus, adjusted by "accrued liabilities" book value, the difference is charged to "changes in fair value gains and losses" account debit. But if the fair value of reward bonus is reduced, there is no adjustment. Only when redeem, we will exchange the difference between the actual value and the fair value recognized in between "change in fair value gains and losses" account credit.

\section{THE EXAMPLE ABOUT REWARD BONUS ACCOUNTING}

In January 1, 2015, a company organized promotion activities, stipulated that all first became member company, giving the bonus 100 points, shopping full 100 yuan gift 10 points, valid for one year, the current exchange policy for the 1 bonus exchange 1 yuan. A customer for a membership card, become the enterprise member, and buy a value 1500 yuan of mobile phone, get a reward 250 points, mobile phone cost 700 yuan. The customer in February 1, 2015, redeems a headset which value of 100 yuan and the cost is 50 yuan. In May 1,2015 , the enterprise has made the adjustment of exchange policy, said the 2 points exchange 1 yuan. As of January 1, 2016, the client does not exchange the remaining points.

- In January 1, 2015 the customer as a member and the purchase of goods (presented stage)
- Confirm the income of the mobile phone Dr: Cash 1755

Cr: Main business income - phone 1500

Taxes payable - VAT (tax) 255

- Confirm the cost of the mobile phone

Dr: Cost - Mobile 700

Cr: Merchandise inventory - phone 700

- Confirm the sales cost

Dr: Selling expenses 250

Cr: Accrued liabilities 250

- The customer redeems a headset in February 1, 2015

- Confirm the income of headset

Dr: Accrued liabilities 117

Cr: Main business income - Headphone 100

Taxes payable - VAT $(\operatorname{tax}) 17$

- Confirm the cost of headset

Dr: Cost - headset 50

Cr: Merchandise inventory - headset 50

- In May 1, 2015, the enterprise has made the adjustment of exchange policy

- According to the new policy, the fair value of the customer remaining reward bonus for 66 yuan, 67 yuan less than before, but it does not accounting.

- January 1, 2016, the customer reward bonus expired

Dr: Accrued liabilities 133

Cr: Operating income 133

\section{REFERENCES}

[1] Ministry of Finance: "About accounting standards Annual Report 2008 Notice," Accounting letter in December 2008.

[2] The Ministry of finance. The accounting standards for enterprises. Beijing: China financial and Economic Publishing House, 2006

[3] Leng Ling. Several issues reward points Accounting. [J]. Accounting Monthly, February 2013

[4] Li Xinyan. Integral business diversity and accounting of the single fuzzy analysis. [J]. Accounting Monthly, January 2015

[5] Ma Ronggui. Customer bonus points accounting briefly. [J]. Communication of Finance and Accounting, 2011(16).

[6] Luo Dan. Analysis of accounting for merchandising activities. [J]. Friends of Accounting, December 2015

[7] Liu Jie. Shopping coupon the comparison of two kinds of accounting treatment ways. $[\mathrm{J}]$. Accounting Monthly, January 2011

[8] Wang Qi. Bonus points of accounting and tax treatment: the comparison of different methods. [J]. Research of Finance and Accounting, September 2014.

[9] Hu Lirong. Business accounting and tax treatment problem analysis and instance members integral parsing. $[\mathrm{J}]$. Chinese business discussion, October 2015

[10] Li Xiafan. Based on analysis of deferred revenue law bonus points business profit manipulation. [J]. Accounting Monthly, August 2011. 